\title{
Do immigrants squeeze natives out of bad schedules? Evidence from Italy
}

\author{
Osea Giuntella
}

Correspondence: osea@bu.edu Boston University, 270 Bay State Road, Boston, MA 02215, USA

\begin{abstract}
This paper documents the effect of immigrant concentration on natives' work schedules. I show that immigrants are more likely to work at non-standard hours (i.e. evenings, nights and Sundays) and that a higher proportion of immigrants in the local labor market is associated with a lower probability of employed natives working non-standard shifts. Results are strongest in sectors and occupations that are more accessible to immigrants. In particular, I find that a 1 standard deviation increase in the foreign population residing in a province is associated to a $4 \%$ reduction in the natives' likelihood of working non standard hours.
\end{abstract}

JEL codes: J15, J81, J61

Keywords: Immigration, Working conditions, Nonstandard schedules

\section{Introduction}

The effects of immigration on economic outcomes for native workers have been widely investigated. While there is an academic consensus that immigration does not have a significant effect on average native wages in the long-run (Borjas 1995; Card 1990; Carrington and Lima 1996; Friedberg and Hunt 1995; Hunt 1992) its effect on the relative wage redistribution across different skill groups is more controversial (Borjas et al. 2011, 2008; Ottaviano and Peri 2012). At the same time, little is known about the effects of immigration on native job quality and working conditions. Several studies document that working late at night or not taking breaks over the weekend is associated with negative health outcomes, less time spent with family and friends, less marital stability, and negative effects on children's well being. In particular, working nonstandard hours has been shown to be associated with negative health outcomes including chronic fatigue, a higher probability of accidents, anxiety, depression, hypertension, obesity, ischemic heart disease, and breast cancer (Costa 1996; Davis et al. 2008; Vyas et al. 2012). ${ }^{1}$ Nonstandard schedules reduce time spent with family and friends, affecting the consumption of relational goods, with important consequences for marital stability (Presser 2000), children's well-being (Lyndall et al. 2006) and more generally individual well-being (Becchetti et al. 2008; Clark 1998; Gui and Sugden 2005; Poggi 2010). Interestingly, Hamermesh 1999 shows that modeling nonstandard hours as a disamenity explains the sharp decline in evening and night hours worked in the U.S. better than industry shifts or demographic changes. Together, this evidence suggests that we cannot neglect nonwage effects,

(c) 2012 Giuntella; licensee Springer. This is an Open Access article distributed under the terms of the Creative Commons 
such as work schedules, when analyzing the overall impact of immigration on the native labor market.

This paper investigates whether an increased presence of immigrants in the local labor market affects the nonwage attributes of natives' jobs. Specifically, this study provides evidence that immigrants have a higher likelihood to work nonstandard hours (relative to natives) and then analyzes the effects of immigration on the likelihood of natives working nonstandard hours.

While the main contribution of this study is to provide an empirical investigation of the relationship between native working schedules and the proportion of immigrants in a local labor market, there are several reasons why immigrants might show a higher tendency to work nonstandard hours and in turn affect the likelihood of natives working non-standard hours. Since most immigrants are lower-skilled (relative to natives) and lower-skilled jobs are more likely to involve nonstandard schedules, the increased number of immigrants could partly crowd out natives from non-standard employment. As discussed by Orrenius and Zavodny (2009), since job amenities are usually considered a normal good and since immigrants have on average less wealth than natives, immigrants might be more willing to trade-off higher wages for worse shifts. Furthermore, because many occupations that have nonstandard shifts may require less interpersonal skills, immigrants with poor Italian-speaking skills and lower communicational skills might have a comparative advantage in working these shifts. Consistently with recent literature on immigration and task specialization (Cortes and Tessada 2011; D'Amuri and Peri 2010; Peri and Sparber 2009), the complementarity of different working schedules and group heterogeneity in the propensity to work nonstandard shifts might induce a negative effect of immigration on the likelihood of natives working nonstandard hours. ${ }^{2}$

Previous studies analyzed whether immigrants are more likely than natives to work in risky jobs (Berger and Gabriel 1991; Orrenius and Zavodny 2009, 2012) as well as differences in time use by nativity (Hamermesh and Trejo 2012; Ribar 2013). However, to my knowledge, only Hamermesh (1998) has examined the impact of immigrants on natives' job quality using US data. In particular, he provides evidence that similar immigrant and native workers enjoy the same job amenities, including the likelihood of working at inferior times and having higher injury rates, and that the immigrant concentration has no consistent effect on the quality of natives' job amenities. However, his analysis and the causal interpretation of his findings are severely restricted by the paucity of data on workplace disamenities and information identifying workers' national origin.

By taking advantage of the Italian Labor Force Survey (LFS), which contains information on both schedules and nativity since 2006, I contribute to the previous literature by investigating the role that immigration plays on native job quality using a much larger sample and by focusing on the impact of immigration on native schedules in the Italian labor market. Italy offers an interesting example of a developed country that has rapidly shifted from origin to destination for migration flows. Until the mid-1980s, the net migration rate was negative, but between 2002 and 2008, Italy attracted about half a million foreign citizens per year, bringing the foreign population to an estimated 4.5 million persons in 2008, which was about 7.5 percent of total population. Substantial variation in the concentration of immigrants across Italian provinces allows us to identify the effect of immigration on native working schedules (see Figure 1). 


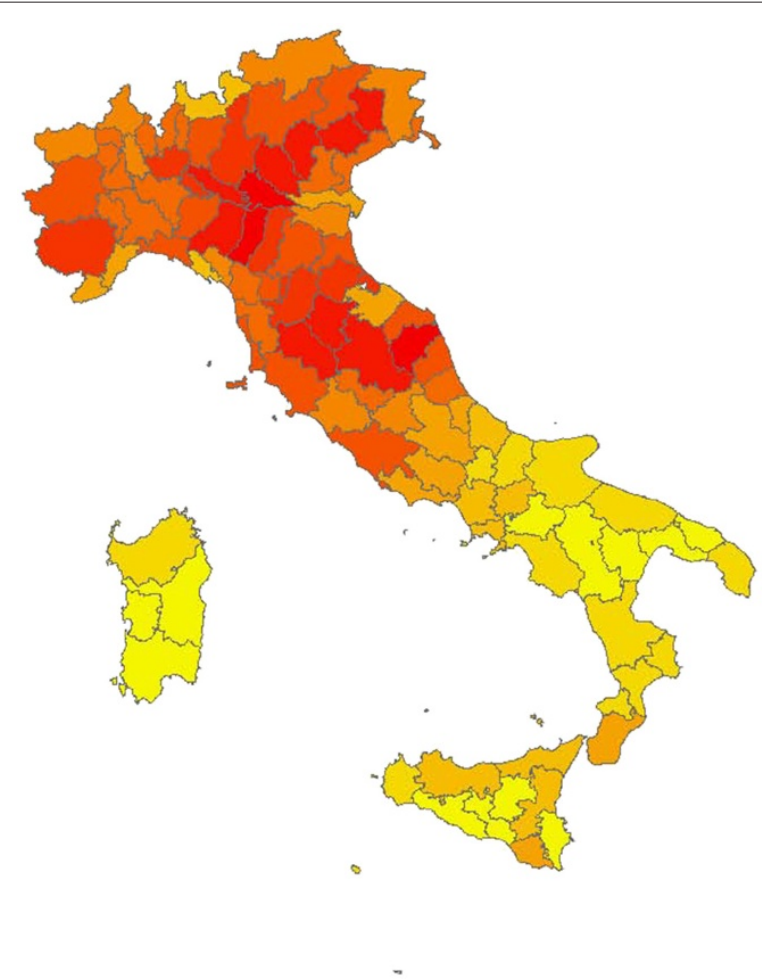

Figure 1 Share of foreign population across Italian Provinces. Provinces are classified in 10 groups (natural breaks) according to the relative concentration of foreign population. The share ranges from 0.005 (pale yellow) to 0.18 (dark red). Source: Municipal Records, 2006-2008, ISTAT.

To account for potential endogeneity in immigrant location choices, I use historical settlement choices of immigrants across local labor markets to instrument for current immigrant distribution across Italian provinces (Card 2001; Lewis 2005). At the same time, I include in the estimation a range of past local labor market characteristics, such as sectoral composition and labor productivity that might affect both immigrant settlements and the demand for nonstandard schedules.

The empirical analysis suggests that immigrants -I exclude EU-15 citizens from the analysis- are more likely to work at nonstandard hours (32\% versus $28 \%$ ) and that a larger proportion of foreign workers in a local labor market reduces the likelihood of working nonstandard hours for natives. In particular, doubling the share of immigrants living in a province (a 1.3 standard deviation increase) reduces the share of natives working nonstandard hours by 2 percentage points (from $28 \%$ to around $26 \%$, a $7 \%$ reduction). The improvement in average working conditions is driven by the changes recorded in sectors that are generally considered more accessible to immigrants (hospitality, retail, transports etc.), while results are not significant in sectors that are typically less accessible to noncitizens and in which natives face lower competition from immigrants (for example, the public or financial sectors). Similarly, there is no significant effect on the schedules of selfemployed workers and highly specialized white collars. This reduction in the likelihood of working nonstandard hours is not associated with significant effects on the probability of being employed or on the number of hours worked. When looking at labor market flows, using the longitudinal component of the Italian LFS, I find that a larger predicted 
foreign population significantly decreases natives' probability of worsening the schedule or remaining employed at nonstandard hours. All other flows do not appear to be significantly shaped by a predictably larger immigrant stock. The results are robust to different specifications as well as different measures of foreign population.

The structure of the paper is as follows. Section 2 provides a description of the data and illustrates the empirical specification and identification strategy. Section 3 presents the main results of the paper. In Section 4 I discuss key results and robustness checks. Concluding remarks are in Section 5.

\section{Data and empirical specification}

\subsection{Data}

The main data sources for this paper are the 2006-2008 waves of the Italian Quarterly Labor Force Survey (LFS). The survey was originally designed to produce cross-sectional data, as each sample household is interviewed for four quarters, but the records can be linked to produce longitudinal data at three, nine, twelve and fifteen month intervals. ${ }^{3}$ The LFS yields a rich set of socio-demographic information on individuals, including hours worked and whether nonstandard hours were worked over the month prior to the survey. Specifically, individuals were asked if they worked in the evening (between $8 \mathrm{pm}$ and $11 \mathrm{pm}$ ), at night (later than $11 \mathrm{pm}$ ), and on Saturday or on Sunday. ${ }^{4}$

Nonstandard hours are quite common in this representative sample of workers. About 14 percent of those employed reported having worked between $8 \mathrm{pm}$ and $11 \mathrm{pm}$ at least twice a week; and another 5.5 percent reported working at least once a week. Work after $11 \mathrm{pm}$ is less frequent, but still more than 10 percent reported having done so one or more times a week. More than one-third of the workers reported working at least twice on Saturday over the previous month, and an additional 10 percent reported working at least once on a Saturday (see Table S14 in the Additional file 1). Approximately 20 percent of the workers reported working on Sunday. In the following analysis, I define nonstandard schedules (NS) as those involving work in the evening or at night at least once a week, or work on Sunday at least once a month. I consider working on Saturday standard for a work schedule, as working on Saturday is common in Italy, especially for retailers and many segments of the public sector (see Table S11 in the Additional file 1). However, I explore different definitions of nonstandard hours in the robustness checks. ${ }^{5}$ As shown in Figures 2 and 3, a significant proportion of employed persons in all sectors and professions work nonstandard hours, ranging from around 80 percent among managers and service workers in the hospitality sector, to less that 10 percent among clerks in the public sector.

Following the traditional area approach, I exploit the heterogeneous geographical distribution of immigrants across Italy as the main source of variability. The analysis focuses on immigrants who are not EU-15 citizens and who are in large part coming from Maghreb and Eastern Europe. ${ }^{6}$ In particular, I combine the micro-data drawn from the LFS with aggregate data on the immigrant distribution from the Survey on demographic balance and resident foreigners provided by the National Institute of Statistics (ISTAT). ${ }^{7}$

This survey includes data on all the immigrants recorded in Municipal records. ${ }^{8}$ The Municipal Records on population report both the native and foreign population for all 8,100 municipalities in Italy and can be aggregated for the 626 Italian local labor markets 


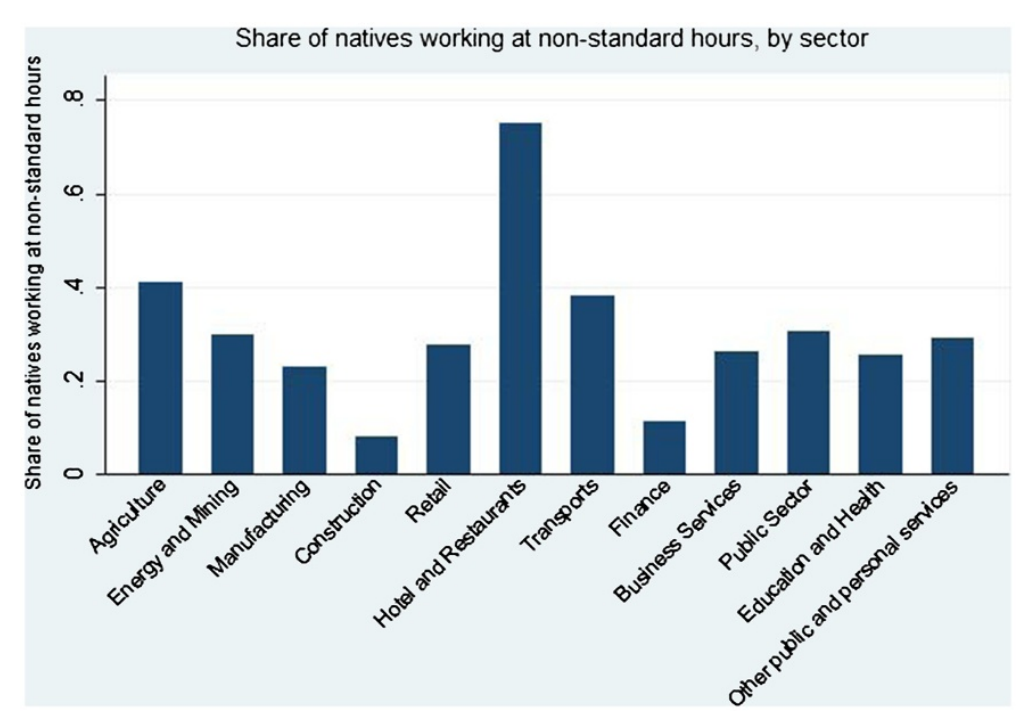

Figure $\mathbf{2}$ Share of natives working at nonstandard hours, by sector of natives working at nonstandard hours, by sector and occupation. Italian Labor Force Survey, 2006-2008.

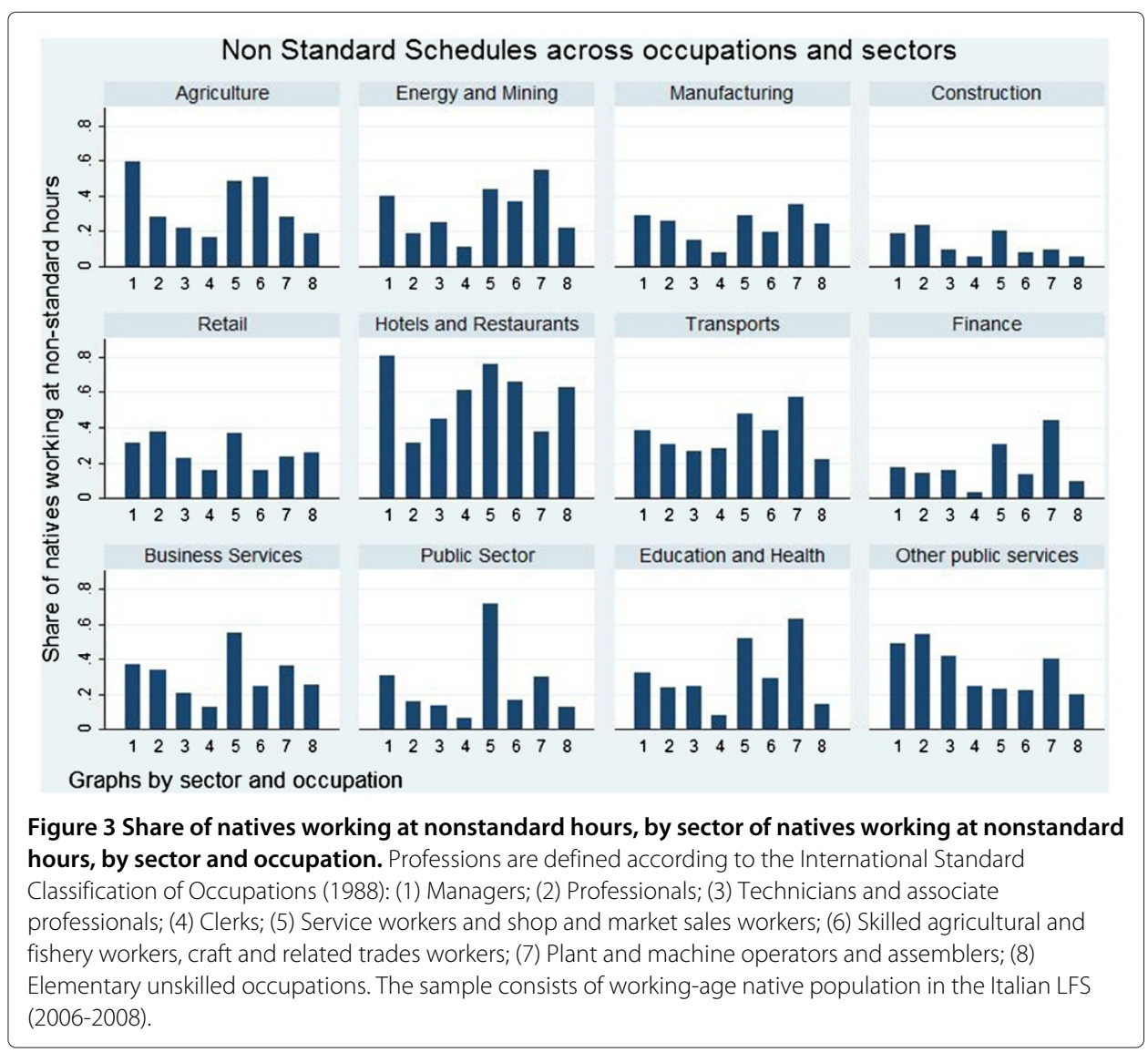


(LLM) as defined by ISTAT. However, information on country of origin and area of residence is publicly available only at the province level. ${ }^{9}$ Since my identification strategy is based on historical settlement patterns of immigrants in Italy by country of origin (e.g., Card (2001)), I use province as the geographic unit in the main specification of this paper. I discuss the results obtained using the population in a LLM as the main explanatory variable in the robustness checks.

Finally, I use province-level aggregate accounts released by ISTAT to describe local economic features as of 1995, the earliest year for which data are available. I consider the 95 provinces that existed in 1995 in order to be consistent with the data that I used to construct my instrument (see the following Section). ${ }^{10}$ In the main specification, the sample is restricted to employed natives between the ages of 15 and 64. I consider the overall working age population when discussing the effects on employment and yearly labor market flows. Summary statistics of the variables used in the analysis are provided in the Additional file 1 (Tables S11, S12, S13).

\subsection{Empirical specification and identification strategy}

To test the effects of immigration on native schedules, I estimate a linear model for the probability that a native worker i works on a nonstandard schedule ${ }^{11}$ :

$$
Y_{i p t}=\alpha+\log \left(F P_{p t}\right) \beta+\log \left(T P_{p t}\right) \lambda+X_{i p t} \gamma+P_{p} \theta+\eta_{p t}+\tau_{p t}+\epsilon_{i p t}
$$

where $Y_{i p t}$ is an indicator equal to unity if $i$, living in province $p$ at time $t$, worked at least once after $8 \mathrm{pm}$ or on a Sunday over the month prior to the interview; the logarithm $F P_{p t}$ measures immigrant concentration in province $\mathrm{p}$ at the beginning of period $t$, controlling for the logarithm of the total population $\log \left(T P_{p t}\right)$ living in province $p$ at the beginning of period $t ; X_{i p t}$ is a set of individual level controls; $P_{p}$ are province level characteristics; $\eta_{p t}$ and $\tau_{p t}$ are region-year and trimester fixed effects, respectively. I use region-year fixed effects to account for regional business cycles, but the results are nearly identical when simply using region and year fixed effects (see Table 1$).{ }^{12}$

Since immigrants do not locate randomly but are likely concentrate where labor demand is higher, areas with more immigrants may also be characterized by more work during nonstandard hours. This effect is likely to be strong in Italy because employment protection legislation is pervasive, and employers tend to satisfy increased demand by raising hours rather than employment (Nunziata 2003). Failure to appropriately control for factors that shape local labor demand could thus induce a spurious positive correlation between immigrant concentration $F P_{p t}$ and the incidence of nonstandard hours in the province. I address this issue by exploiting historical settlement patterns of immigrants in Italy by country of origin (e.g., Card (2001)). These patterns are able to predict the current foreign population in a given local labor market since immigrants tend to reside where previous immigrants from the same country are established (Bartel 1989). At the same time, past settlements are unlikely to be correlated with more recent positive labor market shocks that might induce a stronger inflow of foreigners to the province. A relevant concern is that there could be unobserved and time invariant province characteristics shaping the immigrant distribution over provinces and the native nonstandard schedule demand and supply. To partially address this concern, I control for the 1995 sectoral composition of value added and sectoral labor productivity. ${ }^{13}$ One might conceive of persistence in business practices. In some provinces firms who adopt nonstandard hours 
Table 1 Effects of immigrants on natives working schedules

\begin{tabular}{|c|c|c|c|c|c|c|}
\hline & (1) & (2) & (3) & (4) & (5) & (6) \\
\hline \multirow[t]{2}{*}{ LS, log (Foreign Population) } & $-0.019 * * *$ & $-0.017^{* * *}$ & $-0.016^{* *}$ & $-0.016^{* * *}$ & $-0.013^{* * *}$ & $-0.013^{* * *}$ \\
\hline & $(0.003)$ & $(0.003)$ & $(0.007)$ & $(0.004)$ & $(0.004)$ & $(0.005)$ \\
\hline \multirow[t]{2}{*}{ 2SLS, log (Foreign Population) } & $-0.016^{* * *}$ & $-0.014^{* * *}$ & $-0.026^{* *}$ & $-0.020^{* * *}$ & $-0.016^{* * *}$ & $-0.016^{* * *}$ \\
\hline & $(0.004)$ & $(0.005)$ & $(0.013)$ & $(0.005)$ & $(0.005)$ & $(0.005)$ \\
\hline log (Total Population) & Yes & Yes & Yes & Yes & Yes & Yes \\
\hline $\begin{array}{l}\text { Individual \& household } \\
\text { characteristics }\end{array}$ & No & Yes & Yes & Yes & Yes & Yes \\
\hline Trimester FE & No & No & Yes & Yes & Yes & Yes \\
\hline Year FE & No & No & Yes & No & No & No \\
\hline Region FE & No & No & Yes & No & No & No \\
\hline Region-Year FE & No & No & No & Yes & Yes & Yes \\
\hline Sector & No & No & No & Yes & Yes & Yes \\
\hline $\begin{array}{l}\text { Province Characteristics as } \\
\text { of } 1995\end{array}$ & No & No & No & Yes & Yes & Yes \\
\hline Occupation & No & No & No & No & Yes & Yes \\
\hline $\begin{array}{l}\text { Past non-standard schedule as } \\
\text { of } 1994\end{array}$ & No & No & No & No & No & Yes \\
\hline Observations & 684,530 & 684,530 & 684,530 & 684,530 & 684,530 & 684,530 \\
\hline \multirow[t]{3}{*}{ Mean of Dep. Var. } & 0.28 & & & & & \\
\hline & Stanc & d errors in & entheses & & & \\
\hline & ${ }^{* * *} p$ & $0.01,{ }^{* *} p<0$ &,$* p<0.1$ & & & \\
\hline
\end{tabular}

Notes: The sample considered is the overall working age population (15-64) employed the time of the interview. All the estimates are weighted using the weights provided in the LFS. The dependent variable is the probability of working at non-standard hours. The measure of immigrant concentration is the logarithm of foreign population (mean 9.78, s.d. 1.08) as defined in the Data Section. Standard errors are clustered at the province level. The data sources are LFS (2006-2008 and 1994), Municipal Records (2006-2008), ISTAT Province Accounts (1995) and Minister of Interior for Residence Permits issued at the province level as of 1995

might continue to do so over time due to competition with other firms along these dimensions. In the presence of such province characteristics the exogeneity assumption would not hold. To take into account of persistences in business practices I include the share of population working nonstandard hours in the province as of 1994 in the robustness checks. Since all the specifications control for regional fixed effects, the existence of an omitted variable not correlated with the observed province characteristics and that varies within the region is unlikely. ${ }^{14}$

For all the above reasons, predicted foreign population stock at a given location is a valid instrument for $F P_{p t}$ in equation (2). Formally, I compute the predicted stock of immigrants in province $p$ in year $t$ as:

$$
\widehat{F P}_{p t}=F P_{p, 0}+\sum_{n=1}^{N} \lambda_{n p, 0} * \Delta_{n t}
$$

where the first term on the right, $F P_{p, 0}$, is the stock of immigrants in the province in the base- year; $\lambda_{n p, 0}$ is the proportion of immigrants from country $n$ in the base-year that live in province $p$; and $\Delta_{n t}$ is the inflow from country $n$ to Italy between the base-year and time $t$. I define the instrument used in the estimation as:

$$
Z_{p t}=\widehat{F P}_{p t}
$$

I obtained from the Ministry of Interior data on the geographic distribution of immigrants by country of origin $\left(\lambda_{n p, 0}\right)$, which refers to the stock of residence permits issued at the province level in $1995 .{ }^{15}$ The span of more than ten years between the base 
year and the sample window should limit concerns that early settlements are correlated with current labor market conditions. First stage estimates (reported in Table S15 in the Additional file 1) show that the predicted share of immigrants using the shiftshare methodology is strongly correlated with the actual share of immigrants living in a province. In particular, $t$ and $F$ statistics of the first stage are above 11 and 107, respectively (column 4, Table S15).

\section{Results}

\subsection{Main results}

Table 2 compares the shares of employed natives and foreigners working nonstandard hours and shows that, in general, immigrants appear to be more likely to work during nonstandard hours. About 32 percent of employed immigrants reported having worked a nonstandard work schedule at least once over the past month, as compared with 28 percent among natives; night-work (after $11 \mathrm{pm}$ ) is less frequent than work between 8 and $11 \mathrm{pm}$ or work on Sunday. Even after controlling for standard socio-demographics, such as age, gender, education, household characteristics (column 4), sector and occupation dummy variables (column 5), and province fixed-effects (column 6), immigrants still appear to work more nonstandard hours than natives. ${ }^{16}$ All the estimates are weighted using the weights provided in the LFS.

I now turn to the main objective of this analysis. The main findings are reported in Table 1. The dependent variable is a dummy variable equal to one for Italian citizens who report having worked nonstandard hours at least once over the survey reference week. I show that a large proportion of foreigners in the local labor market affect the workschedule of natives. In particular doubling the share of immigrants residing in a province - a 1.3 standard deviation increase - is associated with a reduction in natives' likelihood

Table 2 Nonstandard working hours, immigrants and natives

\begin{tabular}{|c|c|c|c|c|c|c|}
\hline & $(1)$ & $(2)$ & (3) & (4) & (5) & (6) \\
\hline & $\mathbf{I}$ & $\mathbf{N}$ & $\mathrm{I}-\mathrm{N}$ & $\mathrm{I}-\mathrm{N}$ & $\mathrm{I}-\mathrm{N}$ & $\mathrm{I}-\mathrm{N}$ \\
\hline \multirow[t]{2}{*}{ Evening } & 0.23 & 0.199 & $0.029^{* * *}$ & $0.014^{* * *}$ & $0.028^{* * *}$ & $0.030^{* * *}$ \\
\hline & & & $(0.002)$ & $(0.002)$ & $(0.002)$ & $(0.002)$ \\
\hline Observations & 35,983 & 684,530 & 720,513 & 720,513 & 720,513 & 720,513 \\
\hline \multirow[t]{2}{*}{ Night } & 0.136 & 0.109 & $0.027^{* * *}$ & $0.014^{* * *}$ & $0.021^{* * *}$ & $0.024^{* * *}$ \\
\hline & & & $(0.002)$ & $(0.002)$ & $(0.001)$ & $(0.001)$ \\
\hline Observations & 35,983 & 684,530 & 720,513 & 720,513 & 720,513 & 720,513 \\
\hline \multirow[t]{2}{*}{ Sunday } & 0.208 & 0.188 & $0.020 * * *$ & 0.002 & $0.020^{* * *}$ & $0.024^{* * *}$ \\
\hline & & & $(0.00)$ & $(0.00)$ & $(0.00)$ & $(0.00)$ \\
\hline Observations & 35,983 & 684,530 & 720,513 & 720,513 & 720,513 & 720,513 \\
\hline \multirow[t]{2}{*}{ Non-Standard Hours } & 0.317 & 0.278 & $0.039^{* * *}$ & $0.018 * * *$ & $0.033^{* * *}$ & $0.036^{* * *}$ \\
\hline & & & $(0.003)$ & $(0.003)$ & $(0.002)$ & $(0.003)$ \\
\hline \multirow[t]{3}{*}{ Observations } & 35,983 & 684,530 & 720,513 & 720,513 & 720,513 & 720,513 \\
\hline & & \multicolumn{5}{|c|}{ Standard errors in parentheses } \\
\hline & & \multicolumn{5}{|c|}{${ }^{* * *} p<0.01$, ** $p<0.05,{ }^{*} p<0.1$} \\
\hline
\end{tabular}

Notes: The sample is restricted to working age population (15-64) employed at time of the interview. All the estimates are weighted using the weights provided in the LFS. In columns 1 and 2 I report summary statistics for immigrants and natives. In column 3 I report the unconditional mean-difference among the two-groups considered. In column 4 I add standard socio-demographic controls ( 5 year-interval age dummies, gender, education dummies (middle school diploma and below, high school diploma, some college and above) family size, family type, number of people in household under 9 years old, between 10 and 18 and older than 65 ). In Column 5 I add sector and occupational dummies. Finally in column 6 I add province fixed effects. Standard errors are in parenthesis. Source: Italian Labor Force Survey, 2006-2008. 
of working nonstandard hours that ranges between 2 and 4 percentage points depending on the different specifications of the model. Since on average $28 \%$ of natives reported working nonstandard hours shifts, the coefficient implies a reduction of $7 \%$ to $15 \%$ of the share of natives working nonstandard hours, which is an economically significant effect. ${ }^{17}$

Column 1 offers results only controlling for the logarithm of total population in province $\mathrm{p}$ at time $\mathrm{t}$. In column 2, I add standard socio-demographic characteristics (education, gender, 5-year interval age dummy variables, marital status, family size, family type, share of children below 9 years old, share of children between 9 and 18 years old, share of individuals over 65 years old in the household). In column 3, I control for region, year and trimester fixed effects. The results still hold when I introduce 12 sectoral dummy variables (ISTAT classification), a full set of dummy variables for the interaction of region and year to account for labor shocks of the labor market (column 4) and a description of relevant economic features of the province as of 1995 (the sectoral composition of value added and sectoral labor productivity). Introducing occupational dummy variables (1 digit, ISCO 88 ) reduces the effect by $15 \%$ (column 5), but the coefficient remains negative and significant. ${ }^{18}$ Finally, including the share of employment during nonstandard hours in 1994, as computed from the corresponding LFS, allows me to capture potentially unobserved and persistent labor market characteristics that affect both the intensity of nonstandard schedules and the immigrant concentration across provinces; the results, reported in column 6 , are substantially unchanged. The IV estimates tend to be larger than the OLS in absolute value when controlling for regional fixed effects and province characteristics. This finding is consistent with the assumption of a positive correlation between the demand for nonstandard hours and immigrant concentration. Since I am interested in capturing the average effect on native working schedules, I use the IV specification reported in column 4 as the baseline. ${ }^{19}$

\subsection{Effects of immigration on hours worked and employment}

The evidence presented above suggests that a larger immigrant concentration in the province changes the incidence of nonstandard work schedules among employed natives. However, a number of factors may contribute to this result. This result may reflect a change in the employment composition from a higher immigrant concentration, whereby the relative share of jobs during nonstandard hours then declines either through selective job destruction or selective job creation. For example, complementarity between low-skill immigrants and high-skill natives may induce the creation of more standard high-skill jobs; on the other hand, substitutability between immigrants and low-skill natives may displace the latter out of nonstandard employment. Alternatively, this result may occur through a rescheduling of individual work toward standard hours facilitated by a larger supply of immigrants working nonstandard hours. Moreover, the decline in nonstandard hours might be associated with a decline in hours worked per week and thus, possibly, earnings. To explore the potential avenues leading through which immigration affects native schedules, I replicate the estimation exercise on a set of complementary dependent variables. The first column of Table 3 reports results for the most preferred specification (see column 4, Table 2). The second column presents results on the effect of immigration on the logarithm of weekly hours worked. I find that a larger foreign presence does not significantly change total hours worked by natives, suggesting that rescheduling work effort is not associated with a change in work intensity. 
Table 3 Effects of immigrants on natives working arrangements, 2SLS

\begin{tabular}{|c|c|c|c|}
\hline \multirow{3}{*}{ Dependent Variable: } & (1) & (2) & \multirow{2}{*}{$\begin{array}{c}\text { (3) } \\
\text { Working-age population(15-64) }\end{array}$} \\
\hline & \multicolumn{2}{|c|}{ Employed population (15-64) } & \\
\hline & Non-Standard hours & Log (Weekly Hours) & Employment Rate \\
\hline \multirow[t]{2}{*}{ log (Foreign Population) } & $-0.020^{* * *}$ & 0.009 & $0.018^{* *}$ \\
\hline & $(0.006)$ & $(0.008)$ & $(0.009)$ \\
\hline Observations & 684,530 & 631,040 & $1,230,660$ \\
\hline Mean of Dep.Var. & 0.28 & 3.56 & 0.56 \\
\hline \multicolumn{4}{|c|}{ Standard errors in parentheses } \\
\hline \multicolumn{4}{|c|}{${ }^{* *} p<0.01,{ }^{* *} p<0.05,{ }^{*} p<0.1$} \\
\hline \multicolumn{4}{|c|}{$\begin{array}{l}\text { Notes: The sample considered in the first two columns is the overall working age population (15-64) employed at the time of the } \\
\text { interview, while in columns } 3 \text { I consider the overall working age population (15-64) including non-employed individuals. 3. The } \\
\text { dependent variables are: the probability of working at non-standard hours (col.1), the logarithm of number of hours worked } \\
\text { (col.2) and the likelihood of being employed (col.3). In the first two columns I used the baseline specification (col.4, Table 1). In the } \\
\text { third column I cannot include sector dummies since I am considering the overall working-age population. The data sources are } \\
\text { LFS (2006-2008), Municipal Records (2006-2008), ISTAT Province Accounts (1995) and Minister of Interior for Residence Permits } \\
\text { issued at the province level as of 1995. }\end{array}$} \\
\hline
\end{tabular}

To establish whether the improvement of labor conditions is caused by immigrants crowding natives out of occupations more likely to involve nonstandard work schedules or whether it is accompanied by the creation of jobs with more standard schedules, I examine the effect of immigration on the probability of being employed (column 3 ). The results show that a lower proportion of natives employed working nonstandard hours is not associated with a decline in employment, and if anything, the results suggest a positive correlation with native employment. Table 4 shows that this coefficient is mostly driven by women, while is not statistically significant for men. Cortes and Tessada (2011) provides evidence of a positive effect on female labor supply through the increase in the supply of household help. These findings may be explained by partial complementarity between immigrants and natives - in particular, native women - and their different propensities to work nonstandard hour shifts (for instance, D'Amuri and Peri (2010); Peri and Sparber (2009)). Furthermore, these results are consistent with recent papers studying the effects of immigrants in Italy and showing the existence of potential complementarities on particular subgroups of the Italian population (Barone and Mocetti 2011; Mocetti and Porello 2010).

\subsection{Panel analysis}

So far, the analysis has been limited to employment status and work schedules at a given point in time. Examining yearly transitions in the labor market allows me to establish whether living in a province with a higher proportion of immigrants affects labor market flows and whether this happens differently for individuals working standard and nonstandard hours. ${ }^{20}$ Similarly, I am able to examine whether employment inflows changed and whether they led to a decline in the proportion of workers with nonstandard schedules. The results are reported in Table 5. The first two columns illustrate the effect of the presence of immigrants in a province $p$ at time $t_{0}$ on the probability of moving from nonemployment (at time $t_{0}$ ) to employment (at time $t_{1}$ ) (NE-E), and to employment with nonstandard hours (NE-NS). In both cases, a larger stock of immigrant workers does not seem to be associated with significant changes in the probability of becoming employed. The same result is obtained for the probability of remaining employed, independent of the type of employment (column 3), and for employed persons with nonstandard and 
Table 4 Immigrants and nonstandard hours, by subgroups, 2SLS

\begin{tabular}{|c|c|c|c|c|c|c|c|c|}
\hline Dependent Variable: & $\begin{array}{c}\text { (1) } \\
\text { Overall }\end{array}$ & $\begin{array}{l}\text { (2) } \\
\text { Men }\end{array}$ & $\begin{array}{c}\text { (3) } \\
\text { Women }\end{array}$ & $\begin{array}{c}(4) \\
\text { Under } 25\end{array}$ & $\begin{array}{c}(5) \\
25-54\end{array}$ & $\begin{array}{c}\text { (6) } \\
\text { Over } 54\end{array}$ & $\begin{array}{c}(7) \\
\text { Low-Skilled }\end{array}$ & $\begin{array}{c}\text { (8) } \\
\text { High-Skilled }\end{array}$ \\
\hline \multirow[t]{2}{*}{ Non-Standard Hours } & $-0.020 * * *$ & $-0.021^{* * *}$ & $-0.019^{* * *}$ & -0.015 & $-0.021^{* * *}$ & $-0.018^{* *}$ & $-0.024^{* * *}$ & -0.010 \\
\hline & $(0.006)$ & $(0.007)$ & $(0.006)$ & $(0.010)$ & $(0.006)$ & $(0.008)$ & $(0.006)$ & $(0.011)$ \\
\hline Observations & 684,530 & 406,111 & 278,419 & 44,860 & 554,563 & 85,107 & 580,925 & 103,605 \\
\hline Mean of Dep. Var. & 0.28 & 0.31 & 0.24 & 0.29 & 0.28 & 0.25 & 0.28 & 0.27 \\
\hline \multirow[t]{2}{*}{$\log$ (hours worked) } & 0.009 & 0.006 & 0.010 & 0.004 & 0.010 & 0.007 & 0.009 & 0.001 \\
\hline & $(0.008)$ & $(0.008)$ & $(0.009)$ & $(0.018)$ & $(0.007)$ & $(0.011)$ & $(0.008)$ & $(0.014)$ \\
\hline Observations & 631,040 & 379,994 & 251,046 & 42,686 & 510,541 & 77,813 & 537,473 & 93,567 \\
\hline Mean of Dep. Var. & 0.56 & 0.67 & 0.44 & 0.23 & 0.72 & 0.32 & 0.53 & 0.78 \\
\hline \multirow[t]{2}{*}{ Employment Rate } & $0.018^{* *}$ & 0.012 & $0.025^{* * *}$ & 0.007 & $0.018^{* *}$ & $0.027^{* *}$ & $0.021^{* *}$ & 0.001 \\
\hline & $(0.008)$ & $(0.008)$ & $(0.009)$ & $(0.013)$ & $(0.008)$ & $(0.012)$ & $(0.009)$ & $(0.011)$ \\
\hline Observations & $1,230,660$ & 603,958 & 626,702 & 195,566 & 770,163 & 264,931 & $1,096,776$ & 133,884 \\
\hline Mean of Dep. Var. & 3.59 & 3.70 & 3.43 & 3.57 & 3.60 & 3.57 & 3.61 & 3.52 \\
\hline \multicolumn{9}{|c|}{ Standard errors in parentheses } \\
\hline \multicolumn{9}{|c|}{${ }^{* * *} p<0.01$, ** $p<0.05$, * $p<0.1$} \\
\hline
\end{tabular}

Notes: The sample considered in the first is the overall working age population (15-64) employed at the time of the interview when we analyze the effect of immigration on non-standard hours and hours worked. The sample is the overall working age population when we analyze the effect on employment rate. All the specifications use the baseline model as specified in col. 4 of Table 1. Standard errors are clustered at the province level. The data sources are LFS (2006-2008), Municipal Records (2006-2008), ISTAT Province Accounts (1995) and Minister of Interior for Residence Permits issued at the province level as of 1995. 
Table 5 Effects of immigrants on natives labor market transitions, 2SLS

\begin{tabular}{|c|c|c|c|c|c|c|c|}
\hline Transitions & $\begin{array}{c}\text { (1) } \\
\text { NE-E }\end{array}$ & $\begin{array}{c}\text { (2) } \\
\text { NE-NS }\end{array}$ & $\begin{array}{l}\text { (3) } \\
E-E\end{array}$ & $\begin{array}{c}\text { (4) } \\
\text { NS-E }\end{array}$ & $\begin{array}{l}\text { (5) } \\
S-E\end{array}$ & $\begin{array}{c}\text { (6) } \\
\text { NS-NS }\end{array}$ & $\begin{array}{c}(7) \\
\text { S-NS }\end{array}$ \\
\hline \multirow[t]{2}{*}{ log (Foreign Population) } & 0.005 & -0.002 & 0.004 & 0.006 & 0.003 & $-0.041^{* * *}$ & $-0.012^{* * *}$ \\
\hline & $(0.00440)$ & $(0.00187)$ & $(0.00412)$ & $(0.00531)$ & $(0.00421)$ & $(0.0124)$ & $(0.00410)$ \\
\hline Observations & 196,221 & 196,221 & 246,119 & 68,347 & 177,393 & 63,465 & 162,815 \\
\hline \multirow[t]{3}{*}{ Mean of the Dep.Var. } & 0.09 & 0.026 & 0.92 & 0.93 & 0.92 & 0.68 & 0.11 \\
\hline & & \multicolumn{6}{|c|}{ Standard errors in parentheses } \\
\hline & & \multicolumn{6}{|c|}{${ }^{* * *} p<0.01,{ }^{* *} p<0.05, * p<0.1$} \\
\hline
\end{tabular}

Notes: $\mathrm{NE}=$ non-employed; $\mathrm{E}=$ employed; NS = employed on non-standard schedule; $\mathrm{S}=$ employed on a standard schedule. Columns headings describe states as $t_{0}-t_{1}$. Samples, NE-E and NE-NS: non employed at $t_{0}$; E-E: employed at to; NS-E: employed on non-standard schedule at $t_{0} ; \mathrm{S}$-E: employed on standard schedule at $t_{0} ; \mathrm{NS}-\mathrm{NS}$ : employed at $t_{0}$ and $t_{1}$, on non-standard schedule at $t_{0}$; S-NS: employed at $t_{0}$ and $t_{1}$, on standard schedule at $t_{0}$. All the estimates presented include standard socio-demographic controls (age dummies, gender, education dummies, family size, family type, number of people in household under 9 years old, between 10 and 18 and older than 65, relevant economic features of the province as of 1995 (the sectoral composition of value added and sectoral labor productivity) and province size and region-year fixed effects as in column 4 of Table 1. Sector dummies are included only when the sample is restricted to the employed population. The data sources are LFS (2006-2008), Municipal Records (2006-2008), ISTAT Province Accounts (1995) and Minister of Interior for Residence Permits issued at the province level as of 1995 .

standard schedules (columns 4 and 5). Finally, in columns 6 and 7, I provide the probability of moving between nonstandard and standard schedules conditional on remaining employed. I detect a large and statistically significant decline in the probability of workers remaining on nonstandard schedules after a year, as well as a decline in the probability of workers worsening their schedules (column 7). ${ }^{21}$

Taken together, the results suggest that the decline in natives' likelihood of working nonstandard hours is not caused by a decline in employment opportunities for the nonemployed, or by a higher destruction rate for jobs with nonstandard hours. Rather, these results appears to occur mainly from a decrease in the probability of workers on a "bad" ("good") schedule remaining in (start working) such nonstandard schedules a year later. In other works natives work hours do not change, but they are more likely to work during a standard schedule. ${ }^{22}$

\subsection{Heterogeneous effects of immigration on work schedules}

In Tables 4, 6 and 7, I investigate whether the overall effect of immigrant concentration on native schedules is driven by specific subgroups of the population. In Table 4, I use the preferred specification and show that while the sign of the effect is always negative in the different subgroups considered, it has different magnitudes and is not significantly different from zero among workers who are college graduates (high-skilled) and under 25. Work schedules of college graduates appear not to be affected by immigration, although a proportion similar to that of less educated groups report having nonstandard work schedules. This finding is consistent with the presumption that the labor market for college graduates is hardly contestable by immigrants. This study does not find significant evidence of a change in hours worked for any of the subgroups considered. I then examine whether improvements in the schedule result from the crowding out of natives from "good occupations". The results confirm that even across the main demographic groups, a lower proportion of natives working nonstandard hours are not associated with a decline in employment. The overall positive coefficient seems to be determined by the positive effect on women and individuals over 54 .

Table 6 shows the impact of immigration on natives' schedules across sectors. One could expect that the impact of immigration should be weaker in those sectors that are less 
Table 6 Immigration and nonstandard hours, by sector, 2SLS

(1)

(2)

(3)

(4)

Construction,

Energy,

Sample:

Overall

Public

log (Foreign Population)

Observations

Mean of Dep.Var.

Manufacturing

Private

$(0.007) \quad(0.007)$

684,530

195,00

0.27

$-0.028^{* * *}$
$(0.007)$

$-0.033^{* * *}$

489,529

(0.009)

0.28

198,957

0.19

Standard errors in parentheses

${ }^{* * *} p<0.01,{ }^{* *} p<0.05,{ }^{*} p<0.1$

Notes: The sample considered in columns 1-3 is the overall working age population (15-64) employed at the time of the interview. The dependent variable is the probability of working at non-standard hours. All estimates follow the baseline specification (col.4, Table 1). The data sources are LFS (2006-2008), Municipal Records (2006-2008), ISTAT Province Accounts (1995) and Minister of Interior for Residence Permits issued at the province level as of 1995. 
Table 7 Immigration and nonstandard hours, 2SLS: blue collars, white collars, self-employed

\begin{tabular}{|c|c|c|c|c|c|}
\hline Sample & $\begin{array}{c}(1) \\
\text { Overall }\end{array}$ & $\begin{array}{c}(2) \\
\text { Blue collars }\end{array}$ & $\begin{array}{c}\text { (3) } \\
\text { White collars }\end{array}$ & $\begin{array}{l}\text { (4) } \\
\text { Highly-specialized } \\
\text { White collars }\end{array}$ & $\begin{array}{c}\text { (5) } \\
\text { Self-employed }\end{array}$ \\
\hline log (Foreign Population) & $\begin{array}{c}0.020^{* * *} \\
(0.005)\end{array}$ & $\begin{array}{c}-0.029^{* * *} \\
(0.010)\end{array}$ & $\begin{array}{l}-0.017^{* *} \\
(0.008)\end{array}$ & $\begin{array}{l}-0.009 \\
(0.021)\end{array}$ & $\begin{array}{l}-0.002 \\
(0.013)\end{array}$ \\
\hline Observations & 684,530 & 233,280 & 271,278 & 52,624 & 179,567 \\
\hline Mean of Dep.Var. & 0.28 & 0.29 & 0.22 & 0.27 & 0.35 \\
\hline \multicolumn{6}{|c|}{ Standard errors in parentheses } \\
\hline $\begin{array}{l}\text { The sample considered in } \\
\text { dependent variable is the } \\
\text { able 1). The data sources } \\
\text { nterior for Residence Perm }\end{array}$ & $\begin{array}{l}\text { ns } 1-3 \text { is } \\
\text { ility of W } \\
\text { (2006-2 } \\
\text { ued at th }\end{array}$ & $\begin{array}{l}\text { Dverall working } \\
\text { hg at non-stan } \\
\text { Municipal Rec } \\
\text { Dvince level as }\end{array}$ & $\begin{array}{l}\text { e population (15-6 } \\
\text { d hours. All estima } \\
\text { Is (2006-2008), IST } \\
995 .\end{array}$ & $\begin{array}{l}\text { employed at the time } \\
\text { follow the baseline sp } \\
\text { Province Accounts (19 }\end{array}$ & $\begin{array}{l}\text { he interview. The } \\
\text { fication (col.4, } \\
\text { and Minister of }\end{array}$ \\
\hline
\end{tabular}

exposed to immigrant competition. ${ }^{23}$ In column 1, I report the main results on the overall sample. From columns 2 and 3, it is clear that the private sector is driving the result. As one may expect, there is no effect of immigrant concentration on working schedules in the public sector (column 2), though the share of natives working nonstandard hours in it is not negligible (see Figure 2). ${ }^{24}$ This result is probably because immigrants have less access to public sector jobs, which are often reserved for Italian citizens. The effect of immigrant concentration is driven by the private sector, where doubling the share foreign population - a 1.3 standard deviation increase - living in a province is associated with a reduction of approximately 4 percentage points in the share of people working nonstandard hours. Within the private sector, I find evidence of significant negative effects in the manufacturing, construction and energy sectors (column 4) and nonfinancial services such as retail, hospitality, and transport (see column 6). In these sectors, a 1.3 standard deviation increase in the foreign population reduces the share of people working nonstandard hours by more than 6 percentage points. The coefficient is much smaller and is not significant in the business and financial services sector (see column 7), which is consistent with the presumption that this sector is less exposed to the immigrant inflow. One might still be concerned that white collar workers may be working nonstandard hours from home rather than in a factory or in a hotel and that this effect might not be completely captured by the sectoral analysis conducted so far. Table 5 shows that the main results are driven by blue-collars (column 2). The coefficient is slightly smaller, but still negative and significant, among white collars (column 3). However, the effect becomes non-significant when focusing on highly specialized white collars (directors and managers), excluding clerks (column 4). There is no significant effect on the working schedules of self-employed (column 5). These results suggest that the effect of immigration on nonstandard hours is driven by occupation that are likely to be conducted at the place of work and in which natives are more likely to face the competition of immigrants. ${ }^{25}$

\subsection{Robustness checks}

In this section, I check the sensitivity of my results with alternative definitions of nonstandard schedules, different measures of foreign population and different specification of the models (see Tables 8, 9 and 10). In column 2 of Table 2, I show that the results hold when considering working on Saturday to be a nonstandard schedule. When I run separate regressions following the baseline model to analyze the effects of immigration on the 
Table 8 Different definitions of nonstandard hours, 2SLS

\begin{tabular}{|c|c|c|c|c|c|c|}
\hline Dependent Variable & $\begin{array}{l}\text { (1) } \\
\text { NS }\end{array}$ & $\begin{array}{c}\text { (2) } \\
\text { NS+Saturday }\end{array}$ & $\begin{array}{c}\text { (3) } \\
\text { Evening }\end{array}$ & $\begin{array}{c}\text { (4) } \\
\text { Night }\end{array}$ & $\begin{array}{c}\text { (5) } \\
\text { Saturday }\end{array}$ & $\begin{array}{c}\text { (6) } \\
\text { Sunday }\end{array}$ \\
\hline \multirow[t]{3}{*}{ log (Foreign Population) } & $-0.020^{* * *}$ & $-0.024^{* * *}$ & $-0.015^{* * *}$ & $-0.013^{* * *}$ & $-0.023^{* * *}$ & $-0.019^{* * *}$ \\
\hline & $(0.006)$ & $(0.008)$ & $(0.005)$ & $(0.003)$ & $(0.003)$ & $(0.006)$ \\
\hline & 684,530 & 684,530 & 684,530 & 684,530 & 684,530 & 684,530 \\
\hline Mean of Dep.Var. & 0.28 & 0.52 & 0.20 & 0.11 & 0.48 & 0.19 \\
\hline \multicolumn{7}{|c|}{ Robust standard errors in parentheses } \\
\hline \multicolumn{7}{|c|}{$* * * 0<01$, ** $p<0.05$, * $p<0.1$} \\
\hline
\end{tabular}

Notes: The sample considered is the overall working age population (15-64) employed at the time of the interview. All estimates follow the baseline specification (see col.4, Table 1). Standard errors are clustered at the province level. The data sources are LFS (2006-2008), Municipal Records (2006-2008), ISTAT Province Accounts (1995) and Minister of Interior for Residence Permits issued at the province level as of 1995.

likelihood of working in the evening, at night, on Sunday and Saturday, respectively, I find negative and significant effects. However, the magnitude of the effect, accounting for the share of natives working each shift, is stronger when I consider the natives' likelihood of working on Sunday and over night as dependent variable. In particular, doubling the foreign population in a province reduces by around 10\% the likelihood of working on Sunday and at night. The effect of immigration is smaller on the likelihood of working at evening $(-7 \%)$ and on Saturday $(-5 \%)$.

In Table 9, I further investigate the robustness of my results to the use of alternative measure of foreign population. In column 2, I use the weights provided by the Labor Force Survey to compute the working-age foreign population living in each province. While there are several issues related to the representativeness of the sample that are discussed at length in Albisinni and Quattrociocchi (2006), the advantage of using this source is that one can restrict the analysis to the effects of the working-age foreign population. Not surprisingly, the results are similar to the main specification as the working-age foreign

Table 9 Alternative measures of foreign population, 2SLS

\begin{tabular}{|c|c|c|c|c|c|}
\hline & $(1)$ & (2) & (3) & (4) & (5) \\
\hline Geographic Unit of Analysis & Province & Province & Province & LLM & LLM \\
\hline Source for FP & MR & LFS & MR & MR & MR \\
\hline \multirow[t]{2}{*}{$\log$ (Foreign Population) } & $-0.020^{* * *}$ & $-0.021^{* * *}$ & -0.014 & $-0.054^{* * *}$ & -0.044 \\
\hline & $(0.006)$ & $(0.006)$ & $(0.049)$ & $(0.003)$ & $(0.033)$ \\
\hline log (Total Population) in Province & YES & YES & YES & NO & $\mathrm{NO}$ \\
\hline $\log$ (Total Population) in LLM & $\mathrm{NO}$ & $\mathrm{NO}$ & $\mathrm{NO}$ & YES & YES \\
\hline Individual and household characteristics & YES & YES & YES & YES & YES \\
\hline Sectoral Dummies & YES & YES & YES & YES & YES \\
\hline Trimester FE & YES & YES & YES & YES & YES \\
\hline Region-Year FE & YES & YES & $\mathrm{NO}$ & YES & $\mathrm{NO}$ \\
\hline Province FE & $\mathrm{NO}$ & $\mathrm{NO}$ & YES & $\mathrm{NO}$ & YES \\
\hline Year FE & $\mathrm{NO}$ & $\mathrm{NO}$ & YES & $\mathrm{NO}$ & YES \\
\hline Province Characteristics as of 1995 & YES & YES & $\mathrm{NO}$ & YES & $\mathrm{NO}$ \\
\hline Observations & 684,530 & 684,530 & 684,530 & 684,530 & 684,530 \\
\hline
\end{tabular}

Standard errors in parentheses

$$
{ }^{* * *} p<0.01,{ }^{* *} p<0.05,{ }^{*} p<0.1
$$

Notes: The sample considered is the overall working age population (15-64) employed at the time of the interview. All estimates follow the baseline specification (see col.4, Table 1). Standard errors are clustered at the geographic unit of analysis. The data sources are LFS (2006-2008), Municipal Records (MR, 2006-2008), ISTAT Province Accounts (1995) and Minister of Interior for Residence Permits issued at the province level as of 1995. 
Table 10 Alternative estimation strategies, 2SLS

\begin{tabular}{|c|c|c|c|c|}
\hline & (1) & (2) & (3) & (4) \\
\hline Estimation Technique & Baseline & Probit & Donald-Lang & Donald-Lang \\
\hline Source of Foreign Population Measure & Baseline & Baseline & Baseline & Baseline \\
\hline \multirow[t]{2}{*}{ log (Foreign Population) } & $-0.020^{* * *}$ & $-0.022^{* * *}$ & $-0.020^{* * *}$ & $-0.021^{* * *}$ \\
\hline & $(0.006)$ & $(0.006)$ & $(0.004)$ & $(0.006)$ \\
\hline log (Total Population) in Province & YES & YES & YES & NO \\
\hline Individual \& household chars & YES & YES & YES & YES \\
\hline Sectoral Dummies & YES & YES & YES & YES \\
\hline Trimester FE & YES & YES & YES & YES \\
\hline Region-Year FE & YES & YES & YES & NO \\
\hline Region FE & NO & NO & NO & YES \\
\hline Year FE & NO & NO & NO & YES \\
\hline Province Characteristics as of 1995 & YES & YES & YES & YES \\
\hline Observations & 684,530 & 684,530 & 285 & 95 \\
\hline \multicolumn{5}{|c|}{ Standard errors in parentheses } \\
\hline \multicolumn{5}{|c|}{$* * * p<0.01$ ** $p<0.05$ * $p<0.1$} \\
\hline
\end{tabular}

Notes: The sample considered is the overall working age population (15-64) employed at the time of the interview. All estimates follow the baseline specification (see col.4, Table 1). Standard errors are clustered at the province level. The data sources are LFS (2006-2008), Municipal Records (2006-2008), ISTAT Province Accounts (1995) and Minister of Interior for Residence Permits issued at the province level as of 1995 .

population is highly correlated with the foreign population in the province and registered in the Municipal Records (MR). It is worth noting that there might be unobserved factors at the province level that are not captured by the main specification of the model. While I control for a set of current and past province characteristics and region-year fixed effects, I do not include province-fixed effects in the baseline model because of lack of enough time-variation in the immigrant population within the provinces between 2006 and 2008. When including province fixed effects, the point-estimate is smaller than the one obtained in the baseline specification (see column 3), yet relevant. In column 4, I present the results obtained using the immigrant population in the LLM as the main explanatory variable. Not having data on foreign population at the LLM's level before 2002, and information on the country of origin of immigrants residing in a LLM, I instrument for the foreign population in a given LLM with the province foreign population predicted using the 1995 distribution of immigrants over Italian provinces. The coefficient remains negative and significant. Province fixed effects (column 5) reduce the magnitude of the coefficient by roughly $20 \%$, but the standard deviation increases by 1 order of magnitude resulting in a non-significant estimate.

In Table 10, I report the results of alternative estimation strategies. In column 2, I present the marginal effects of a probit model. Finally, columns 3 and 4 show the coefficients obtained by correcting standard errors following the Donald and Lang (2007) two-step approach. In column 3 (4), the data are collapsed at the province-year (province) level after controlling for individual characteristics in the first step. The results following this approach are substantially identical to the baseline specification (column 1).

\section{Discussion}

This study has made no claims about welfare. It suggests that a higher concentration of immigrants reduces the likelihood of natives working nonstandard hours, but it does 
not discuss whether this is to be considered an overall improvement for native workers. The results might be explained in a model allowing for complementarity between labor services at standard and nonstandard schedules and heterogeneity in the willingness to work nonstandard hours. Similar to the mechanism studied in previous literature on immigration and task specialization (D’Amuri and Peri 2010; Peri and Sparber 2009), immigration will cause a reallocation of native labor supply toward standard schedules, which will partially compensate for the depressing effect of immigration on nonstandard wages. However, the paucity of data on the timing of work, wages, and nativity severely restricts the scope of any welfare analysis and the ability to test all the implication of a theoretical model.

The Italian LFS released information on wages (only on employees) in January 2010, but the LFS does not include information about overtime compensations. It is possible that the wage compensation for working nonstandard hours may actually make natives better off and that at least some of them may have preferred working those hours. Using the latest available data, which is for the first two semesters of 2009, I do not find evidence of a negative effect of immigration on natives' wages (see Table S16 in the Additional file 1). Furthermore, it is not even clear what the general equilibrium effects on consumers who might be affected by the lower availability of natives working at nonstandard hours would be. Estimates of the impact of immigration on the log of weekly hours worked in Table 3 show no significant effects across all subgroups. This result suggests that at a given employment rate, workers are working the same number of hours but are rescheduling their work toward more regular hours, as confirmed by the panel analysis reported in Table 5. Unfortunately, I do not have information on natives overall job satisfaction, which would be relevant to address possible welfare implications.

For the above reasons, it is difficult to derive any welfare claim from these results. However, it is worth noting that contracts in Italy are not particularly flexible and that the labor market is characterized by a high level of employment protection legislation. In several occupations, a worker's bargaining power is relatively low, and employers impose a schedule on workers. This is particularly true in the sectors driving the results (hospitality, retail, transport and manufacturing). Furthermore, as mentioned earlier in the paper there is abundant evidence on the negative effect of irregular shifts (and in particular night shifts) on health outcomes, marital stability and children well-being (Lyndall et al. 2006; Presser 2000, Vyas et al. 2012). Thus, even if it is not clear whether the results imply an overall improvement for native workers, this paper suggests that the effects on natives' working conditions, such as schedules, should not be neglected when evaluating the overall impact of immigration on the native population.

\section{Conclusion}

This paper extends previous literature on the impact of immigration by examining the effect on natives' working schedules. I exploit the heterogeneity of immigrant distribution across Italian provinces as a major source of identification. To isolate the endogeneity of immigrant concentration across the country, I use previous settlements of immigrants. The results suggest that immigration reduces natives' likelihood of working nonstandard hours but that it does not significantly affect employment and hours worked. The reduction in native nonstandard hours is significant across the main demographic sub-groups. However, I do not find significant effects on high-skilled workers, highly 
specialized white collars, self-employed and in sectors in which immigrants have less of a presence (that is, the public sector or the financial sector). These effects are robust when using different empirical specifications and different measures of foreign population. Though it is difficult to disentangle whether this effect is due to the rescheduling of working hours or due to changes in the employment flows, the results from a panel analysis suggest that immigration raises the probability of improving natives' schedules and that it reduces the natives' risk of having undesirable schedules. This study is unable to test whether the results suggest an overall improvement for native workers, given the limited information on wages and overall job satisfaction. While this paper is not sufficient to provide an assessment of the welfare effects of increased immigration, it provides a first insight into a neglected margin of investigation.

\section{Endnotes}

${ }^{1}$ In a recent article published in the British Medical Journal, Vyas et al. (2012) analyze the findings of 34 studies and found that shift work was associated with a $23 \%$ increased risk of heart attack, a $5 \%$ increased risk of stroke and that people working night shifts are the ones at the highest risk for vascular diseases. They confirm the results of previous studies which found irregular shifts to be correlated with high blood pressure, diabetes and obesity and suggest that the lack of sleep, poor eating habits, higher smoking rates and lower levels of physical activity are likely to affect the health of shift workers. See also http://www.bbc.co.uk/news/health-18996082

${ }^{2}$ One could also think that working nonstandard hours may affect the social relationships of immigrants less; if an immigrant's family and friends did not migrate, they may not need to synchronize with the schedule of other people. Finally, depending on their religious beliefs, some immigrants may be more willing to work on weekends.In addition, immigrants might have fewer alternatives than natives. The fear of losing a job and the concern that this might also affect their legal status may increase their willingness to work nonstandard hours.

${ }^{3}$ From the survey design, $50 \%$ of the cross-sectional household sample for each quarter should be reinterviewed twelve months later Discenza 2004.

${ }^{4}$ The question on the survey is "Have you worked at night (evening, Saturday, Sunday) in the last four weeks?" Possible answers are (1) Yes, at least twice per week (or month, if question is about weekends); (2) Yes, less than twice per week (or month, if question is about weekends); (3) No; (4) Do not know.

${ }^{5}$ Similar results are found when using as an alternative dependent variable the likelihood of being employed in occupations involving shifts and or having worked on shifts in the last month.

${ }^{6}$ I excluded all the immigrants who were EU-15 citizens. Mocetti and Porello (2010) discuss in detail the changes in immigrant flows to Italy in the last fifteen years. After the EU enlargement (2007) Romanians are the largest minority group, followed by Albanians and Moroccans. These three groups account for $39 \%$ of the working-age immigrant population, after excluding EU15 citizens (source: LFS, 2006-2008).

${ }^{7}$ As mentioned earlier in the paper, the LFS data allow us to distinguish natives from immigrants in the sample. One potential advantage of using the LFS to construct the explanatory variable is that one can compute the concentration of immigrants 
across different segments of the population (which would not be possible from nonsurvey administrative registries). This computation allows one to focus on the effects of working-age immigrant concentration. However, the LFS survey is only representative at the regional level and the sampling error might be particularly high for the share of immigrants who represent only a minor fraction of the total population. Furthermore, sampling weights are stratified to match population in the second trimester of each year. For the above reasons I chose to use municipal records in the baseline specification. In the robustness checks (see Table 9), I show that the results hold when using the LFS survey with the LFS weights to compute the province-year share of immigrants in the working-age population. The correlation between the share of foreign population computed using the LFS and the same measure computed using the Municipal records is 0.98 .

${ }^{8}$ Data are publicly available for the period from 2002 to 2010. Immigrants who illegally entered Italy are not included in the sample, while those who overstay might still show up in Municipal records. However, Fasani (2009) provides evidence that the distribution of undocumented immigrants across provinces tend to mirror legal ones.

${ }^{9}$ In Italy, a province (in Italian: provincia) is an intermediate administrative division between the municipality (comune) and the region (regione).

${ }^{10}$ However, I obtain similar results using more recent province classifications. The results are available upon request.

${ }^{11}$ In Additional file 1: Table S12, I report the marginal effects obtained using a probit model.

${ }^{12}$ This specification allows me to add province fixed effects (rather than using a set of current and past province characteristic) and to exploit variation over time for identification. In practice, I do not have enough time-variation in the immigrant population within a province between 2006 and 2008. However, while the estimate becomes nonsignificant when including province fixed effects, the point estimate is only slightly smaller than in the baseline model (see Table 8).

${ }^{13}$ When including data on local industry composition (available at the province level 1999 onwards), results are substantially unchanged and if anything the coefficients is slightly higher in absolute value (coef.: 0.022; s.d.: 0.008).

${ }^{14}$ Italy is subdivided in 20 regions.

${ }^{15}$ The earliest year for which I obtained data from the Ministry of Interior on foreign population by country of origin and province of residence in electronic format is 1995 .

${ }^{16}$ Descriptive statistics of the main variables used are provided in the Additional file 1 (Tables S11, S12 and S13).

${ }^{17} \mathrm{~A}$ one standard deviation increase in the share of immigrants in a province would be associated with a $4 \%$ decrease in native non-standard hours. Equivalently, a $15 \%$ increase in the immigrant population in a given province would be associated with a $1.1 \%$ reduction in the native nonstandard hours.

${ }^{18}$ One concern is that my results might be picking up the fact that employers assign rookies the "bad" schedules in a market in which immigrants are the new "employees". However, controlling for other job characteristics such as job tenure, a dummy for those on a temporary contract and job position results are substantially unchanged. In particular the coefficient of interest slightly increases: coef., 0.024 ; s.d., 0.08 . 
${ }^{19}$ However, most of the robustness checks still hold when controlling for occupational characteristics and past nonstandard schedules. The results are available upon request.

${ }^{20}$ As mentioned in the Data Section, the LFS survey was designed to produce crosssectional data, but as each sample household is interviewed for 4 quarters, the records can be linked to produce longitudinal data at 3, 9, 12 and 15 months. From the survey design, $50 \%$ of the cross-sectional household sample for each quarter should be reinterviewed a year later.

${ }^{21}$ Equivalently, living in province with a higher share of immigrants at time $t_{0}$ is associated with a higher likelihood of being on a regular schedule at time $t_{1}$ among those who were working non-standard hours at time $t_{0}$.

${ }^{22}$ This is consistent with the fact that a larger share of immigrants is also associated with a $5 \%$ decrease in the native likelihood of being employed in occupation involving shifts (coef., 0.016; s.e., 0.007) and a 10\% decrease in the likelihood of having worked on shifts in the last month before the survey (coef., -0.018; s.e., 0.006).

${ }^{23}$ Mocetti and Porello (2010) show that about $80 \%$ of the immigrants in Italy are bluecollar workers and most of them work in the manufacturing and construction sectors or in the personal services industry.

${ }^{24}$ The public sector includes hospitals, public services, police, and the army.

${ }^{25}$ The LFS includes a question asking whether individuals worked from home in the last month. About $5.4 \%$ of the employed population worked from home at least once in the four weeks preceding the survey. When restricting the analysis to those workers who did not report working at home, results are substantially unchanged (coef., 0.022; s.e, 0.005), while the coefficient is small and non-significant when focusing on those who reported working at home at least once in the month before the survey.

\section{Additional file}

Additional file 1: Appendix.

Competing interests

The IZA Journal of Migration is committed to the IZA Guiding Principles of Research Integrity. The author declares that he observed these principles.

\section{Acknowledgements}

I am grateful to Claudia Olivetti, Daniele Paserman and Alfonso Rosolia for their comments and guidance, to the anonymous referees and the editor Denis Fougère for their valuable suggestions. I also benefited from discussion with Leonardo Becchetti, Rania Gihleb, and Fabrizio Mazzonna. I would like to thank all the participants to the European Society for Population Economics (2012), the CReAM Interdisciplinary Conference on Migration (2011), and seminar attendees at the Boston University Empirical Micro-Lunch(2010), and the Bank of Italy (2009). Data on foreign residence permits were kindly provided by the Minister of Internal Affairs-Security Department. Any errors are my own. Responsible editor: Denis Fougère

Received: 2 August 2012 Accepted: 23 October 2012 Published: 18 December 2012

\section{References}

Albisinni M, Quattrociocchi L (2006) Gli stranieri nella rilevazone sulle forze di lavoro. Metodi e Norme 27. http://www3. istat.it/dati/catalogo/20060315_01/mn0627stranieri_nelle_forze_di_lavoro.pdf. Accessed 13 Nov 2012.

Barone G, Mocetti S (2011) With a little help from abroad: the effect of low-skilled immigration on the female labor supply. Labour Econ 18(5): 664-675

Bartel AP (1989) Where do the new U.S. immigrants live. J Labor Econ 7(4): 371-391

Becchetti L, Pelloni A, Rossetti F (2008) Relational good, sociability and happiness. Kyklos 61 (3): 343-363

Berger MC, Gabriel PE (1991) Risk aversion and the earnings of US immigrants and natives. Appl Econ 23(2): $311-318$

Borjas GJ (1995) The economic benefits from immigration. J Econ Perspect 9(2): 3-22

Borjas GJ, Grogger J, Hanson GH (2008) Imperfect substitution between immigrants and natives: a reappraisal. NBER

Working Paper. http://www.nber.org/papers/w13887.pdf Accessed 13 Nov 2012 
Borjas, G J, Grogger J, Hanson GH (2011) Substitution Between Immigrants, Natives, and Skill Groups. NBER Working Paper: 17461. http://www.nber.org/papers/w17461.pdf. Accessed 13 Nov 2012

Card D (1990) The impact of the Mariel boatlift on the Miami labor market. Ind Labor Relat Rev 43(2): 245-257

Card, D (2001) Immigrant inflows, native outflows, and the local labor market impacts of higher immigration. J Labor Econ 19(1): 22-64

Carrington WJ, Lima P (1996) The impact of 1970s repatriates from Africa on the Portuguese labor market. Ind Labor Relat $\operatorname{Rev} 42(9): 330-347$

Clark AE (1998) Measures of Job Satisfaction: What Makes a Good Job? Evidence from OECD Countries. OECD Labour Market and Social Policy Occasional Papers: 34. http://ideas.repec.org/p/oec/elsaaa/34-en.html. Accessed 13 Nov 2012

Cortes P, Tessada J (2011) Low-skilled immigration and the labor supply of highly skilled women. Am Econ J: Appl Econ 3(3): 88-123

Costa G (1996) The impact of shift and night work on health. Appl Ergon 27(1): 9-16

D'Amuri F, Peri G (2010) Immigration and Occupation in Europe. Centro Studi Luca d'Agliano Development Studies Working Paper. http://www.dagliano.unimi.it/media/WP2010_302.pdf. Accessed 13 Nov 2012

Davis K, Goodman WB, Pirretti AE, Almeida DM (2008) Nonstandard work schedules, perceived family well-being, and daily stressors. J Marriage Fam 70(4): 991-1003

Discenza AR (2004) Weighting procedure for longitudinal data of the Italian Labour Force Survey. Procedura di Riporto per i Dati Longitudinali della Rilevazione Trimestrale sulle Forze di Lavoro. [http://www.sis-statistica.it/files/pdf/atti/ RSBa2004p29-32.pdf Accessed 13 Nov 2012]

Donald SG, Lang K (2007) Inference with difference-in-differences and other panel data. Rev Econ Stat 89(2): 221-233

Fasani F (2009) Undocumented Migration in Italy - a Country Report. Clandestino Project European Commission Report. http://irregular-migration.net/typo3_upload/groups/31/4.Background_Information/4.4.Country_Reports/ Italy_CountryReport_Clandestino_Nov09_2.pdf Accessed 13 Nov 2012

Friedberg R, Hunt J (1995) The impact of immigrants on host country wages, employment and growth. J Econ Perspect 9(2): 23-44

Gui B, Sugden R (2005) Economic and Social Interaction: Accounting for Personal Interactions. Cambridge University Press, Cambridge

Hamermesh D, Trejo S (2012) How do immigrants spend their time? The process of assimilation. J Popul Econ: 1-24. doi:10.1007/s00148-012-0440-x

Hamermesh DS (1998) Immigration and the quality of jobs Hamermesh D, F D Bean e (eds) Help or Hidrance? The Economic Implications of Immigration for African Americans. The Russel Sage Foundation, New York

Hamermesh, D S (1999) The timing of work time over time. Econ J 109(452): 37-66

Hunt J (1992) The impact of the 1962 repatriates from Algeria on the French labor market. Ind Labor Relat Rev 45(3): $556-572$

Lewis EG (2005) How do local labor market in the U.S. adjust to immigration?. Philadelphia Fed Business Review (Q1). http://www.phil.frb.org/phil_mailing_list/research-and-data/publications/business-review/2005/q1/brq105el.pdf. Accessed 13 Nov 2012

Lyndall S, Clements MS, Rosemary JK, Broom DH, Rennie MS (2006) Unsociable work? Nostandard work schedules, family relationships, and children's well being. J Marriage Fam 68(2): 394-410

Mocetti S, Porello C (2010) How does immigration affect native internal mobility? New evidence from Italy. Reg Sci Urban Econ 10(6): 427-439

Nunziata L (2003) Labor market institutions and the cyclical dynamics of employment. Labour Econ 10(1): 31-53

Orrenius PM, Zavodny M (2009) Do immigrants work in riskier jobs. Demography 46(3): 531-551

Orrenius PM, Zavodny M (2012) Immigrants in risky occupations. IZA Discussion Paper (6693). http://papers.ssrn.com/ sol3/papers.cfm?abstract_id=2101980. Accessed 13 Nov 2012

Ottaviano GIP, Peri G (2012) Rethinking the effects of immigration on wages. J Eur Econ Assoc 10(1): 152-197

Peri G, Sparber C (2009) Task specialization, immigration, and wages. Am Econ J: Appl Econ 1(3): 135-169

Poggi A (2010) Job satisfaction, working conditions, aspirations. J Econ Psychol 31 (6): 936-949

Presser HB (2000) Nonstandard work schedules and marital instability. J Marriage Fam 62(1): 93-110

Ribar DC (2013) Immigrants' time use: A survey of methods and evidence In: Zimmermann KF, Constant AF (eds) The International Handbook on the Economics of Migration. Edward Elgar Publishing, Cheltenham. forthcoming

Vyas MV, Garg AX, lansavichus AV, Costella J, Donner A, Laugsand LE, Janszky I, Mrkobrada M, Parraga G, Hackam DG (2012) Shift work and vascular events: systematic review and meta-analysis. BMJ 345. http://www.ncbi.nlm.nih.gov/ pubmed/22835925. Accessed 13 Nov 2012.

doi:10.1186/2193-9039-1-7

Cite this article as: Giuntella: Do immigrants squeeze natives out of bad schedules? Evidence from Italy. IZA Journal of Migration 2012 1:7. 